\title{
OVER DE KENNIS, DIE DE ARABIEREN VOOR DE KOMST DER PORTUGEEZEN VAN DEN INDISCHEN ARCHIPEL BEZA'TEN.
}

In een opstel, dat in het $5^{\mathrm{e}} \mathrm{dl}$. IIIe volgreeks dezer Bijdragen onder den titel Ptolemaeus en de Indische Archipel geplaatst is, heb ik onderzocht welke kennis de Grieken en Romeinen van den Oost-Indischen Archipel bezaten, en ik ben daarin tot de slotsom gekomen, dat, in tegenspraak met het gewone gevoelen, dat Ptolemaeus reeds het geheele schiereiland van Achter-Indië en een deel der kusten van China zou gekend en beschreven hebben, zijne kennis van het vaste land van Azië niet verder ging dan tot ongeveer $12^{\circ}$ N.B., daar waar de Mergui-archipel zich langs de westkust van dat schiereiland uitstrekt, ofschoon van de zuidoostwaarts gelegen eilanden de naam van het eiland Java hem ook reeds ter oore was gekomen. Die hoofdstelling, van mijn opstel is tot nog toe onbestreden gebleven; slechts een der drie bijvoegsels, dat namelijk waarin ik over de verklaring van den naam Java handelde, heeft de heeren A. B. Cohen Stuart, H. Kern, en Neubronner van der Tuuk de pen tegen mij doen opvatten, den eersten in een brief, den andere in een stukje insgelijks in deze Bijdragen geplaatst en den derde in een courant en op die hem zoo eigenaardige wijs, die mij ontslaat van de plicht om er verder notitie van te nemen. De heeren Cohen Stuart en Kern hebben mij gewezen op den naam Yawa als den anderen vorm van den naam des eilands en de laatstgenoemde heeft er een betoog bij geleverd dat gierst(eiland) wel niet de beteekenis van dat woord behoeft geweest te zijn, maar dat die verklaring toch niets ongerijmds bevat. $1 \mathrm{k}$ geloof dat wij het best doen met de 
stukken tot nader te laten rusten, daar wij op 't oogenblik toch viet veel verder zouden komen, voomamelijk omdat ik mij niet op de hoogte acht om hun argumenten ten volle te kunnen waardeeren.

In dit opstel nu ben ik van zins een stap verder te doen en te onderzoeken wat er van de kennis is, die men in de middeleeuwen van ons Indië bezat, en wel vooruamelijk door tusschenkomst der Arabieren. - De bronnen, die wij voor dat onderzoek hebben, zijn driederlei, doch zoo dat zij zich tot tweeërlei laten terugbrengen. Het rijn namelijk òf rechtstreeksche reizen, ò losse berichten, welke laatste, hetzij ze in algemeene woordenboeken of in beschrijvingen zijn verzameld, hetzij ze hier en daar in verhalen, zoo als bij voorbeeld de bekende reiźen van Sindbad den zeeman in de Duizend-en-één-nachtvertellingen, voorkomen, in deze beide gevallen in karakter niet verschillen, behalve dat in die woordenboeken ook wel namen van plaatsen worden gevonden, waarvan men niets anders vermeld vindt dan de ligging, hetgeen zulke namen zeker minder geschikt maakt om in vertellingen te worden opgenomen. Wilde men zich nu tot taak stellen om al die woordenboeken of beschrijvingen te excerpereu, dan zou het nut van zulk een arbeid de moeite niet beloonen. Men zou in onderzoekingen moeten vervallen omtrent het meerdere of mindere gezag dier brounen; men zou alle mogelijke handschriften moeten vergelijken ten einde de juiste lezingen der eigenuamen vast te stellen, op gevaar af van toch nog niet het rechte te treffen, en dan zou eindelijk het meegedeelde nog meestal van dien aard zijn, dat het ons niet aanbood, wat ons bij de verklaring dier namen zou kunnen leiden. - Het belangrijkste Arabische werk over Indië zal wel dat van den geograaf Edrisi zijn. Hij voltooide zijne "Uitspanningen van hem die begeerig is om grondig de verschillende streken der aarde te leeren kennen" (كتاب نزهت المشتاق في اخترات الافاق) in Januarij 1154 aan het hof van Koning Roger I van Napels, die hem de beschrijving had opgedragen van een planispherium, dat hij van zuiver zilver ter zwaarte van $450 \mathrm{rom}$. ponden, ieder pond van 120 drachmen, had laten maken. Tot de zamenstelling van dat werk gebruikte Edrisi een aantal boeken, waarvan hij de titels opgeeft, zoo als onder anderen ook de geographie van Ptolemaeus, wieus Kattigara ik dan ook in Edrisi's werk als een ouden be- 
kende terugvind. Trouwens wat vind ik niet al in dien kraam van westersche en oostersche geleerdheid! Doch andere Arabische geographen maken het niet beter. Hoe dikwijls vind ik niet dezelfde plaatsnamen opgegeven als verschillende, al naar mate het onduidelijke Arabische schrift toeliet uit hetzelfde woord er verscheidene te lezen, en desniettemin van elk der zoo vermenigvuldigde plaatsen weder bijzonderheden meegedeeld als bestonden zij alle in werkelijkheid! Voeg hierbij dat die bijzonderheden ook wel eens in naauw verband schịnen te staan met die namen, op den klank af met bekende Arabische woorden vergeleken, en men zal erkennen, dat ér aan geen doorgaande verklaring te denken valt.

Wij kunnen dus niet beter doen dan de reizigers op den voet te volgen en te trachten ons van hunnen reisweg eene goede voorstelling te maken. Veel van die reisverhalen zijn er nu echter niet, ja eigenlijk bepaalt zich onze voorraad slechts tot een paar of tot een enkelen, die hier in aanmerking kan komen. De meeste Arabieren, die naar het verre Oosten gingen, hebben slechts mondelinge verhalen van hunne reizen gedaan en daarmede de stof geleverd voor die menigte wonderbaarlijke en verwarde vertellingen over die vreemde landen en eilanden, die zeker doorgaans in de eerste plaats moesten dienen om belangstelling in hunne personen en opzien tegen zulke verre tochten op te wekken, waarbij dan een verkeerd opgegeven naam of de overdrijving van de een of andere bijzonderheid niet in aanmerking kwam. De eenige reiziger, die ons eenigszins tot gids kan strekken, is een zekere Soliman, van wien men overigens niets weet, maar wiens reis ons verhaald wordt in een boekje, dat in 851 is opgesteld en waarbij door een ander, een zeventig jaren later, eeue soort van verslag daarover met verscheiden bijvoegsels is gevoegd. Het boekje is laatstelijk met vertaling en verklarende aanteekeningen uitgegeven door wijlen Prof. Reinaud te Parijs, in 1845, onder den titel van: Relation des voyages faits par les Arabes et les Persans dans l'Inde et à la Chine. Aangezien het eerste gedeelte der reis, van Basra tot Ceilon, ons hier geen belang inboezemt, verplaatsen wij ons in eens naar het laatstgenoemde eiland, het Serendib der Arabieren. Zie hier wat er in het boekje verder te lezen staat.

"Die zee van Herkend bevat in dezelfde richting als Serendib eenige eilanden, die niet talrijk, maar zeer groot ziju en waar- 
van men de juiste uitgestrektheid niet kent. Onder die eilanden behoort al-Ramni, dat verdeeld is onder een aantal vorsten, en waarvan de oppervlakte, naar men zegt, acht of negen honderd parasangen is. Men vindt er goudmijnen en ziet er plantages, fansoer geheeten, uit welke meu de beste kamfer krïgt. Aan die eilanden zijn weder andere onderworpen, en daaronder an-Neyan. Deze zijn rijk aan goud en de inwoners voeden zich met de vrucht van den kokosboom. Zij gebruiken die om hunne spijzen te bereiden en smeeren het ligchaam met de olie er van in. Wanneer iemand van hen wil trouwein, kan hij geene vrouw krịggen, tenzij hij haar het hoofd van een hunner vijanden aanbiedt; heeft hij er twee gedood, dan kan hij twee vrouwen trouwen; vijftig, dan kan hij er vijftig trouwen, al naar het aantal schedels. De oorsprong van dit gebruik is hierin gelegen, dat de bewoners van dat eiland omringd zijn van vijanden; hij derhalve die zich het dapperst gedraagt in den strijd wordt het meest van allen geëerd. - Het eiland Ramni brengt eene menigte olifanten voort, zoo als mede brazilie-hout en bamboes. Meu merkt er een volkstam op die menschen eet. Het wordt door twee zeeën bespoeld, die van Herkend en die van Sjelahet. - Na dit eilaud komen de eilanden Lendjebaloes, die zeer bevolkt zijn. Mannen en vrouwen gaan er naakt, behalve dat de vrouwen hare naaktheid met boombladeren bedekken. Wanneer een schip in de nabijheid voorbij vaart, naderen de mannen in booten, groote of kleine, en laten zich voor amber en kokosuoten ijzer. in ruil geven. Zij hebben geen stoffen noodig, aangezien men in die streken warmte noch koude lijdt. - Voorbij die eilanden zijn twee andere, gescheiden door eene zee, die men Andaman noemt. De inwoners van die eilanden eten de menschen levend op. Zij zijn zwart en hebben kroes haar, terwijl hun gelaat en huune oogen iets schrikverwekkends hebben. $Z_{i j}$ hebben voeten van wel een elleboog lang. Zij gaan nakt en hebben geen vaartuigen. Hadden zij die, dan zouden zij alle menschen opeten, die daar voorbijvaren. Soms worden de schepen door den wind verhinderd hunne reis voort te zetten; is dan hun watervoorraad uitgeput, dan nadert het scheepsvolk de inwoners en vraagt om water; somtijds vallen zij zoo in de macht van dezen en worden dan voor het grootste gedeelte gedood. - Voorbij dat eiland zijn er bergen, maar die buiten de route liggen en die, zegt men, zilvermịjnen bevatten. Die bergen zijn onbewoond, doch een schip, dat ze wil aandoen, zal daar 
niet altijd in slagen. Om er te komen, heeft men tot verkenningspunt een piek, al-Kosjami geheeten. Op een schip, dat er eens in de nabijheid voorbijvoer, kreeg men die in 't oog en wendde men den steven daarheen. Den volgenden morgen begaf men zich in eene boot derwaarts en legde vuur aan met hout dat men er kapte; meteen begon het zilver te smelten en zoo ontdekte men de mijnen. Men nam zooveel zilver mede als men begeerde, maar op hetzelfde oogenblik, dat men weder aan boord was gekomen, begon de zee oustuimig te worden, zoodat men verplicht was al het zilver, dat men meegenomen had, weder weg te werpen. Te vergeefs wilde men naar den berg terugkeeren; men heeft dien niet kunnen terug vinden. Dergelijke gevallen komen op zee dikwijls voor; men zou al de eilanden niet kunnen optellen, die moeijelijk te genaken zijn en die de zeelieden met moeite herkennen; er zijn er zelfs, die zij niet bereiken kunnen." En dan eenige bladzijden verder :

"Wanneer men die zee (die van Herkend) over is, dan komt men ter plaatse genaamd Lendjebaloes. De bewoners dier plaats verstaan geen Arabisch, noch eenige andere taal door de kooplieden gesproken. De mannen dragen geen kleederen; zij zijn blank en hebben weinig haar op het lichaain. De reizigers zeggen, dat zij nooit hunne vrouwen gezien hebben. De mannen komen allen aan boord in schuitjes, die van een enkelen boomstam gemaakt zijn, en brengen kokosnoten, suikerriet, bananen en palmwijn, die eene witte kleur heeft. Drinkt men dien terstond als hij uit den kokospalm getapt is, dan is hij zoo zoet als honig; doch laat men hem een uur staan, dan wordt hij als wijn en laat men hem zoo weder een dag of wat, dan verandert hij in azijn. De inwoners ruilen dat alles in tegen ijzer. Soms vinden zij een weinig amber, dat zij eveneens voor eenige ijzeren voorwerpen afstaan. Overigens wordt die landel uitsluitend gevoerd door middel van teekens, daar men elkaar niet verstaat. Die menschen kunnen zeer vlug zwemmen. Somtijds ontstelen zij het ijzer aan de kooplieden zonder hun iets in de plaats te geven. - Van daar gaan de schepen onder zeil naar eene plaats, Kalah-bar geheeten. Het woord bar beteekent zoowel rijk als kust. Kalahbar is eene onderhoorigheid van den vorst van Zabedj, wiens rijk rechts van Indië ligt en in zijn geheel aan eenen koning gehoorzaamt. De kleeding der inwoners is van grof katoen, groot en klein dragen zij er een enkel stuk van. De schepen vinden te Kalahbar drinkwater in putten, dat men 
boven welwater en regenwater verkiest. De afstand tusschen Koelam, in de nabijheid der zee van Herkend, en Kalahbar is eene maand reizens. - Verder begeven de schepen zich naar eene plaats die Betoemah heet, alwaar drinkwater te vinden is voor wie het verlangt. Men heeft 10 dagen noodig om er te komen. Daarna nemen de schepen humuen koers naar Kedrendj, en bereiken dat in 10 dagen. Ook daar vindt men zoet water. Op de Indische eilanden is dat evenzeer het geval; graaft men er putten, dan vindt men drinkbaar water. Te Kedrendj is een hooge berg, waarheen de slaven en de dieven somtijds ontvluchten. - De schepen gaan voorts naar eene plaats, Senef geheeten, op een afstand van 10 dagen verwijderd; men vindt er insgelijks drinkwater; men voert van daar de aloë uit, die assenfi genoemd wordt. Die plaats is een vorstendom. De inwoners zijn bruin en ieder hunner kleedt zich met twee stukken katoen. - Wanneer de schepen zich van drinkwater voorzien hebben, gaan zij onder zeil naar Senderfoelat. Dit is de naam van een eiland, om hetwelk te bereiken men 10 dagen noodig heeft eu waar men drinkbaar water vindt. - Van daar komen de schepen in de zee Sandji en zeilen ze door de Poorten van China. Deze poorten bestaan in bergen, die door de zee bespoeld worden en tusschen welke eene opening is, waar de schepen doorheen gaan. - Wanneer door Gods beschikking de schepen gelukkig en wel Senderfoelat verlaten hebben, richt men den koers naar China, dat na eene maand bereikt wordt. Zeven dagen van die maand gebruikt men om de straten door te komen, die de bergen vormen, en is men die poorten door en in de golf gekomen, dan komt men in zoet water en begeeft zich naar de stad, waar de schepen gewoonlijk ankeren, als zij in China komen, en die Khanfoe heet."

"Men verhaalt dat er op een eiland, Molhan geheeten, tusschen Serendib en Kalah, in de zee van Indië, in het oosten, een zwarte volkstam woont eu die naakt gaat. Valt iemand uit een ander land hun in hander, dan hangen zij hem op met het hoofd omlaag, snijden hem in stukken en eten hem bijna raauw op. Het aantal van die zwarten is aanzienlijk; zij wonen op hetzelfde eiland en hebben geen koning. Hun voedsel bestaat uit visch, bananen, kokosnoten en suikerriet. Zij wonen in eene soort van bosschen en te midden vau het riet. - Er is zegt men, in de zee een kleine vliegende visch; die visch, zeesprinklaan geheten, vliegt boven de oppervlakte van het water. 
Men spreekt ook nog van een anderen zeevisch, die, uit het water komende, in de kokosboomen klimt en er het sap uit opdrinkt; daarna keert hij weder in zee terug. Men maakt ook nog gewag van een zeedier, dat op een kreeft gelijkt; zoodra dat dier uit zee komt, verandert het in steen en men voegt er bij, dat die steen eene zalf voor zekere oogziekte oplevert. Dicht bij Zabedj is er, zegt men, een berg, de Vuurberg geheeten, dien men met geen mogelijkheid kan naderen. Over dag. ziet men er rook uit opstijgen en 's nachts vlammen. Aan den voet is eene bron van koud en zoet water; ook is er eene andere bron van zoet en warm water."

"De hoofdstad van Zabedj ligt tegenover China, met eene maand reizens over zee en zelfs minder, als de wind gunstig is, tusschen beide. - De koning, van die stad draagt den titel van Maharadja. Men zegt dat zijne hoofdstad negeu honderd parasangen oppervlakte heeft. Hij heerscht over een groot aantal eilanden, die zich tot op een afstand van 1000 parasangen en meer uitstrekken. Tot zijue onderhoorigheden behooren het eiland Sarbaza, dat 400 parasangen groot, en het eiland Arrami, dat achthonderd parasangen groot is. Op het laatstgenoemde eiland vindt men brazilie-hout, kamfer enz. De koning van Zabedj telt onder zijne bezittingen het eiland Kalah, dat halfweg China en Arabië gelegen en tachtig parasangen groot is. Kalah is het middelpunt van den handel in aloë, kamfer, sandelhout, ivoor, al-kali-lood, ebbenhout, braziliehout, specerijen vau allerlei soorten en eene menigte voorwerpen, die het te lang zou zijn om op te noemen. Daarheen is het dat zich tegenwoordig de handelstochten uit Oman richten en van daar vertrekken wederom de lieden, die op Arabië handel drijven. - Het gezag van den Maharadja strekt zich over al die verschillende eilanden uit. Dat waar hij zijn verblijf houdt is zeer vruchthaar en de woningen volgen er elkander in onafgebroken rijen. lemand, wieus woorden alle vertrouwen verdienen, heeft verzekerd, dat wauneer in de staten van Zabedj de hanen, evenals bij ons, 's morgens kraaijen om den dageraad an te kondigen, zij elkander beantwoorden over eene uitgestrektheid van honderd en meer parasangen, hetgeen komt van de onafgebrokene reeks van dorpen, die elkander regelmatig opvolgen. Er zijn dan ook geen woeste gronden in dat eiland, noch ook vervallen gebouwen. Zoo men in dat land reist, kan men het doorrijden zooveel men wil, en verveelt dit of kan het 
rijdier niet verder, dan kan men vertoeven waar men verkiest. Een van. de vreemdste dingen, die men ons van het eiland Zabedj verhaald heeft, betreft een van zijne oude koningen. Die koning heette Maharadja. Zijn paleis lag aan een tjeladj die aan zee begon, d. w. z. den breeden benedenloop eener rivier, die beurtelings den invloed van ebbe en vloed ondervindt, zooals dit ook met de Tigris voor Bagdad en Basra het geval is. Het water vormde een kleinen vijver, daar waar het het paleis van den vorst bespoelde. Tederen morgen verscheen de opziener van het paleis en bood den koning een klomp goud aan van de gedaante van een baksteen; ieder klomp woog een zeker aantal ponden. Daarop wierp dan de opziener, in 's konings tegenwoordigheid, dien klomp in dien vijver. Bij vloed bedekte het water dien klomp en alle andere, die er in lagen, en onderscheidde men er geen meer; maar had het water zich teruggetrokken, dan ontwaarde men al die klompen, die daar in den zonneschijn zeer lagen te schitteren. Wanneer de koning audientie verleende, zette hij zich in eene zaal aan het water en met het gelaat daarheen gekeerd. - Dat gebruik was onveranderlijk; iederen dag wierp men een klomp goud in het water, en zoo lang de vorst leefde raakte men dat goud niet aan. Doch stierf hij, dan liet zijn opvolger die klompen er uithalen zonder er een enkelen in te laten. Men telde ze, smolt ze, en verdeelde het goud onder de prinsen van het hof, mannen en vrouwen, kinderen, beambten en eunuchen, naar verhouding van hunnen rang en der voorrechten aan ieders betrekking verbonden. Hetgeen er overbleef werd onder de armen en de ongelukkigen uitgedeeld. Men had er voor gezorgd dat het aantal goudklompen en hum gezamenlijk gewicht opgeteekend werd, en er werd dan aangeteekend dat die en die vorst op dat tijdstip en zooveel jaren geregeerd en zooveel klompen goud van zooveel gewicht in het water had doen werpen en dat deze na zijn dood onder zijne bloedverwanten verdeeld waren. De vorst, die het langst geregeerd en het grootste aantal klompen goud bijeen gebracht had, was het meest in eere. - De verhalen in dat land deelen mee, dat er in oude tijden een vorst was van Komar, het land, dat de aloë al-komari voorbrengt. Dat land is geen eiland; het ligt op het vasteland tegenover Arabië. Geen rijk is volkrijker, dan dat. Iedereen gaat er te voet. De bewoners onthouden zich van drank en overspel, niets onbetamelijks geschiedt er in hun land. Komar ligt in de richting van 
het rijk van deu Maharadja en het eiland Zabedj. Tusschen beide rijken ziju er tien dagreizen varens of iets meer, zoo er weinig wind is. - Men verhaalt, dat eertijds in dat rijk Komar een jongeling regeerde, die van nature wat onbedacht was. Deze vorst zat eens in zijn paleis, dat aan eene rivier gelegen was gelijk aan de Tigriș in Irak; tusschen het paleis en de zee was er een dag afstand. De vizier was bij den koning tegenwoordig en men sprak over den Maharadja en zijn rijk, over den glans, die van hem uitstraalde, en over het aantal zịner onderdanen en der eilanden, die hem gehoorzaamden. Plotseling zeide de vorst tot zijn vizier: "Ik heb een wensch, dien ik wel zou willen vervuld zien." De vizier, die innig aan zijn meester gehecht was en zijne onbedachtzaamheid kende, zeide: "En welke is die wensch, o Koning?" Deze hervatte: "Ik wenschte voor mij het hoofd van den koning van Zabedj op een schotel te zien." De vizier begreep, dat het jaloerschheid was, die den koning aldus deed spreken, en antwoordde: "Het zou mij leed doen, wanneer de Vorst dergelijke wenschen koesterde. Nooit heeft er eenig gevoelen van haat tusschen ons en dat volk bestaan, noch in woorden, noch in daden. Het heeft ons nooit kwaad gedaan. Daarenboven bewoont het een afgelegen eiland en onderhouden wij naauwlijks eenige betrekkingen met elkaar. Ook heeft die koning nooit eenig verlangen getoond om zich van ons rijk meester te maken. Laat daarom niemand te weten komen; wat gij, o Koning, gezegd hebt, en herhaal er geen woord van." Die woorden verbitterden den koning, die niet naar zulk een verstandigen raad wilde luisteren en zijn wensch in het bijzijn van zijne beambten en voornaamste hovelingen herhaalde. Zijne woorden gingen van mond tot mond, zoodat zij eindelijk den Maharadja zelf ter oore kwamen. Deze nu was iemand van veel geestkracht, vlug van verstand en rijk aan ondervinding; hij was van middelbaren leeftijd. Hij ontbood zijn vizier en deelde hem het nieuws mede, dat hij vernomen had. Daarop voegde hij er bij: "Na al wat er mij van dien jongen dwaas verhaald is, na die wenschen, die jeugd en inbeelding bij hem doen opkomen, en na het zeggen, dat mij thans van hem meegedeeld is, kunuen wij hem niet meer ongemoeid laten, want zoo iets zoude verkeerd zijn voor een vorst en zoude hem vernederen en in minachting brengen." Hij beval hem stilzwijgendheid aan omtrent hetgeen tusschen hen was voorgevallen, maar gelastte te gelijkertijd, dat hij duizend schepen zou uit- 
rusten van middelmatige grootte, met alle oorlogsbenoodigdheden, en dat hij ieder schip zou voorzien van wapenen en krịggslieden, zoo veel als het schip er bergen kon. Intusschen liet de vorst het gerucht verspreiden, dat hij eene reis wilde doen door de eilanden van zijn rijk. Hij liet de goeverneurs dier eilanden zijn voornemen bekend maken en zoo werd dat plan overal ruchtbaar en maakte ieder goeverneur zich gereed om zijn Maharadja op eene waardige wịze te ontvangen. Doch toen alle toebereidselen gemaakt en alle beschikkingen genomen waren, besteeg de vorst de vloot en begaf zich met zijne troepen naar het rijk Komar. De koning en zijne krijgslieden maakten gebruik van den tandenstoker; iedereen reinigde zich de tanden verscheidene malen op een dag; men droeg den tandenstoker bij zich en scheidde er niet van, dan om hem an een bediende toe te vertrouwen. De koning van Komar vernam het gevaar, dat hem dreigde niet, voordat de vijandelijke vloot reeds de rivier opgezeild was, waar zịjne hoofdstad aan lag, en de soldaten van den Maharadja ontscheept waren. Deze overviel den koning van Komar dus onvoorziens en makte hem gevangen, terwijl zijne dienaars op de vlucht gingen. Toen liet de Maharadja algemeene veiligheid verkondigen en zich op den troon van den koning van Komar neergezet hebbende, deed hij dezen en zijn vizier, die insgelijks krijgsgevangen gemaakt was, voor zich komen en sprak den koning aldus aan: "Wie heeft u een wensch doen koesteren, die boven uwe krachten was en die $\mathrm{u}$, zoo gij hem verkregen hadt, geenerlei voordeel zou aangebracht, ja dien zelfs de beste uitslag niet zoude gewettigd hebben?" De koning antwoordde niets. Daarop ging de Maharadja voort: "Indien gij, behalve het verlangen om mijn hoofd op een schotel $\mathrm{u}$ aangeboden te zien, ook den wensch geuit hadt om mijne staten te verwoesten en er u meester van te maken, dan zou ik u en uw land thans op dezelfde wijs behandelen; maar gij hebt slechts één ding begeerd en daarom zal ik u ook slechts dit aandoen en daarna naar mijne staten terugkeeren, zonder iets te hebben aangeraakt van hetgeen $\mathrm{u}$ toebehoort; ieder zal weten dat men niet moet ondernemen, wat de krachten en de middelen, die men ontvangen heeft, te boven gaat, en zich gelukkig moet achten van zijne gezondheid te kunnen genieten zoo lang men die bezit." Toen liet hij den koning onthoofden en zeide tot den vizier: "Gij hebt u gedragen als een waardig vizier; ontvang de belooning voor uwe handelwijs; ik weet dat gij goeden 
raađ aan uwen meester gegeven hebt, maar hij heeft dien niet willen aannemen. Zoek thans iemand, die in staat zij den troon te beklimmen na dien dwaas en stel dien in zijne plaats." Onmiddellijk daarop keerde de Maharadja naar zijne staten terug, zonder dat hij noch een der zijnen iets had aangeroerd van hetgeen den koning van Komar toebehoorde. In zịne staten teruggekeerd zette hij zich op zijn troon met het gelaat naar de rivier gekeerd en liet den schotel voor zich plaatsen, waarop het hoofd van den koning van Komar zich bevond. Tegelijkertijd riep hij zijne hofgrooten bijeen en verhaalde hun hetgeen er was voorgevallen benevens de gronden, die hem gedwongen hadden aldus te handelen. De volken van Zabedj wenschten hem daarop geluk en baden hem alles goeds toe. De Maharadja gaf toen last het hoofd te wasschen en te balsemen en het in eene vaas gedaan hebbende zond hij het aan den vorst, die toen koning van Komar geworden was. Het hoofd ging verzegeld van een brief van den volgenden inhoud: "De eenige reden, die mij er toe gebracht heeft om uwen voorganger te behandelen gelijk ik gedaan heb, was zijne verkeerde manier van handelen jegens mij en de noodzakelijkheid om eene les te geven aan zijus gelijken. Ik heb hem behandeld zooals hij het mij had willen doen. Thans meende ik u zijn hoofd te moeten terugzenden, daar ik geen belang er bij heb het te bewaren en ik geen eer hecht aan de overwinning, die ik op hem behaald heb." - Toen het nieuws van die gebeurtenissen onder de koningen van Indië en China verbreid werd, rees de Maharadja bij hen in aanzien. Van dat oogenblik af keerden de vorsten van Komar elken morgen, wanneer zij opstonden, het gelaat naar het land van Zabedj en bogen zich ten teeken van eerbied jegens den Maharadja." - Zie daar alles wat die Relation des voyages ons van den Indischen Archipel meedeelt.

Beginnen wij om, gelijk wij als uitgangspunt der reis het eiland Ceilon hebben aangenomen, thans ook het eindpunt er van te bépalen. Dat is de plaats Khanfoe. Reinaud houdt het voor het Gampoe van Marco Polo, de haven van Hang-tsjeoe foe, eene stad, die eenige dagreizen hooger op ligt. Burck evenwel, de laatste mij bekende uitgever van Marco Polo's Reizen, ontkent de identiteit van dat Gampoe en het Khanfoe der Arabieren en acht het buiten twijfel dat dit laatste hetzelfde is als Kanton, zoo als Renaudot, die in 1718 die Relation het eerst bekend maakte, en Deguignes, de schrijver van de Histoire des Huns, 
dit ook meenden. Het schịnt dat Polo's beschrijving van het beroemde Quinsai, hetzelfde als Hang-tsjeoe-foe, wel eenigen invloed gehad heeft op Reinaud's gevoelen, terwijl de berichten der Chineezen, die van Arabieren en Perziërs weten te vertellen, die te Kanton gevestigd waren, van den anderen kant het gevoelen van hen, die Kanton en Khanfoe voor hetzelfde houden, komen ondersteunen. Welke plaats de voorkeur verdient, zal uit het verband met de overige aanlegplaatsen, die op reis werden aangedaan, moeten worden opgemaakt.

De eerste dier plaatsen was Lendjebaloes. - Reinaud laat bij zijne verklaring van de reisroute van Soliman de schepen zoo lang mogelijk de kust volgen en ze niet eer dan bij de monding der Godaveri in de golf van Bengalen den koers oostwaarts, naar Achter-Indië, nemen. Ik geef gaarne toe dat het zeer juist gezien is om bij het terug zoeken van dien ouden reisweg van Soliman op die wijs te beginnen, maar Reinaud had, wanneer de genoemde plaatsen niet terstond weer te vinden waren, ze niet met geweld daar moeten blịven zoeken. De winden en stroomen hebben natuurlijk hun aandeel gehad bij het houden van dien weg en de stroom, die van Ceilon eerst tot ongeveer de genoemde hoogte op eenigen afstand langs de kust loopt om zich dan noord-oostwaarts naar de kusten van Arakán te richten, kan zeer wel gemaakt hebben dat die schepen niet onnoodig zoovele plaatsen aan de kust aandeden. Doch er kan ook toeval in het spel geweest zijn, zoodat de naam van deze of gene haven, die zij toch nog aandeden, niet bewaard is gebleven.

Zie toch eens tot welke verklaringen Reinaud moest komen om den weg, dien hij zich nu eenmaal als den waren voorstelt, niet te verlaten! Van de eilanden Lendjebaloes makt hij eilanden in den omtrek van Kalimier-punt, van Kalahbar Zuid-Koromandel, van Beitoema Madras, van Kedrendj eindelijk ongeveer Masulipatam, van waaruit de schepen dan verder oostwaarts hielden. Maar de onwaarschijnlijkheid, dat van Ceilon uit "in diezelfde richting " - men zou dus meenen in eene oostelijke - de eerste station zou geweest zijn op eenige eilanden ten noorden, zoo klein, dat een gewone kaart ze niet opgeeft; dat een volgende eenvoudig land van Tjola zou genoemd zijn (bar kan land beteekeuen en Kalah houdt Reinaud voor fautief voor Kolah= Tjola, dus Kalahbar=Tjola-mandalam, d. i. Koromandel); een derde eene voorstad van Madras zou geweest zijn, een vierde 
Masulipatam, waarvoor ten minste nog Koringa beter met den Arabischen naam zou overeenkomen, en dat er geen enkele bekende naam zou genvemd zijn, terwijl er toch zoo vele handelsplaatsen zijn op deze kust; die onwaarschijnlijkheid is van dien aard, dat zij ons reeds anstonds tegen die verklaring inneemt. En deze blijkt geheel verwerpelijk, wanneer wij in Lendjebaloes de eerste 1 voor een overblijfsel van het lidwoord houdende, dat woord lezen al-Nedsjabaloes, d. i. de Nikobaren. Men vindt het Arabische woord ook gespeld

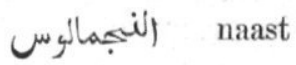

لنبجبالوس لن لنخ يالوس en Reinaud heeft op zijne kaart bij zijne Mémoire sur l'Inde dan ook niet geaarzeld de juistheid dier verklaring, reeds door Stüwe, Handelszüge der Araber, en misschien ook al door anderen gegeven, te erkennen. Ook Ptolemaeus kende de Nikobaren reeds onder den naam van Baroesai. Zij blijken van oudsher eene aanlegplaats in de golf van Bengalen geweest te zijn, waar men op de terugreis uit het noorden van Achter-Indië door wind en stroomen van zelf heen gedreven werd. Maar is nu deze verklaring juist, en er schijnt geen grond te zijpn om daaraan te twijfelen, dan vervalt met een de geheele grondslag, dien R. voor zijne verklaring dier reisroute heeft aangenomen. Trouwens hij was ook buitendien niet houdbaar. Zie bijvoorbeeld Beitoemah. Zoo die naam goed geschreven is, dit voegt er R. er ten minste nog bij, schijnt, zegt hij, het gevoelen dergenen waar, die daarin den naam van de stad San-Thomé gezien hebben. Deze plaats is echter niet meer dan eene voorstad van Madras, dat door zijne gevaarlijke reede in vroeger eeuwen wel nooit eene aanlegplaats voor schepen zal geweest zijn, hetgeen het nu nog niet is. De grond waarop de verklaring rust is deze, dat de Arabische naam zich laat oplossen in beit Toema, dat wil in het Arabisch en in het Syrisch zeggen huis van Thomas, waarmede dan de plaats zou bedoeld zijn, waar de apostel Thomas begraven ligt. Maar er is gees naam die zoo verschillend wordt geschreven als deze. Het Arabische schrift, dat zoovele letters alleen door het aantal bijgevoegde punten onderscheidt, geeft hier ruime anleiding tot verwarring. Ik voor mij twijfel ten minste niet of in Betoemah, Tenoemah, Nenoemah, Sjoemah, schuilt een en dezelfde naam. Ik ga zelfs nog verder en zie in سريرخ ,سوبزه , سبوره , لاسمه steeds nog hetzelfde eiland. Maar welke naam nu de juiste mag zijn? Quatremère, en na hem Lassen, lazen Netoemah en maakten er de Natoena-eilanden 
van! De vorm, die zich het best tot een bekenden naam brengen laat, is $x_{0}, \mathrm{l}$, waarin men wel Borneo heeft willen zien, omdat er gezegd wordt kamfer te groeien en men voor Sumatra, waar die ook nog groeit, reeds een ander eiland had, en ook misschien om de syllabe bor; maar dat mij toeschijnt met het ons uit mijn vorig opstel reeds bekende Soevarna over een te komen; een naam die volgens de getuigenis van den Arabischen schrijver alBiroeni aan de eilanden van den Zabedj, dat is Java en onderhoorigheden, gegeven werd. Daarmede komen de verhalen omtrent het eiland met dien proteus-naam zeer goed overeen. De productie bewijst nog zoo veel niet; op handelsplaatsen kunnen natuurlijk de voortbrengselen van verschillende eilanden bijeengebracht ziju. Nog minder is aan opgaven omtrent grootte en afstanden te hechten; die vallen, even als de verhalen van allerlei merkwaardigheden, die men op die eilanden vinden zou, te zeer onder het gebied der fantaisie om er op te vertrouwen. Wat van de bewoners gemeld wordt, kan ons meestal beter op den weg brengen. Zoo staat er van het eiland Sjoema, bij Edrisi, dat de inwoners er de foeta dragen, d. i. een lap katoen om het midden (hetgeen eigenlijk meer op te vatten is in dien zin, dat zij beschaafder zijn dan die van andere eilanden, die geheel naakt loopen) en dat zij Boeddha-dienaars zijn en hunne dooden verbranden. Zoo iets behoeft nu wel niet uitsluitend op een enkel eiland te slaan, maar doet dit toch blijkbaar op de eilanden van Zabedj, d. i. op Soevarna.

Wanneer nu Lendjebaloes de Nikobaren en Beitoemah Java en onderhoorigheden zijn, dan zal men, zoo men op de juistheid der route vertrouwt, Kalahbar tusschen die beide in zoeken, maar ook al hecht men aan de naauwkeurigheid dier volgorde niet veel gewicht, zal men geneigd zijn Kalahbar in diezelfde streken te zoeken, en men wordt in dit vermoeden bevestigd door de mededeeling, dat Kalahbar ook eene, onderhoorigheid van Zabedj is. Reinaud, die in Kalahbar Zuid-Koromandel ziet, verwijdert die moeijelijkheid, dat het land aan den vorst van Zabedj zou onderworpen zijn door eenvoudig eene fout in dat woord Zabedj te veronderstellen. Wat de Arabische schrijver van de etymologie van Kalahbar zegt, dat de laatste lettergreep van dat woord het bekende bar zou wezen, daaraan behoort men niet te hechten. Hij kan daartoe gebracht zijn door de vermelding van nog één Kalah, zonder dat suffix, hetzij dat daar hetzelfde eiland mee bedoeld is of een ander, waarin ik dan 
nog eerder eene verbastering van het Sanskritsche vära zou zien. In dat Kalah ziet Reinaud Point-de-Galle, Walckenaer Keddah op het schiereiland van Malakka, anderen OedjoengSalang, alias Junk-Ceilon, een vrịj aanzienlijk eiland in die streek, anderen wederom Koewala, het bekende Maleische woord, dat riviermonding beteekent en als eerste deel van geographische eigennamen dikwijls voorkomt: al te maal verklaringen, die op ééne na weinig waarschijnlijkheid voor zich hebben. Ik zou ten minste, wanneer ik kiezen moet, dien naam ook het liefst in de buurt van Oedjoeng-Salang zoeken. Ook den naam Kedrendj kan ik niet met zekerheid t'huis brengen. Andere lezingen zijn, althans ik houd de namen voor dezelfde, هريح هرنج misschien zelfs De omgeving, waarin men ook bij Edrisi die namen vindt, wijst ons duidelijk weder naar Java, maar welk eiland bedoeld is, terwijl de naam misschien nog andere lezingen toelaat, daarop is weder niet met zekerheid te antwoorden. Men heeft er onder anderen Kidorong, den naam eener kaap in Sĕrawak, in willen vinden, omdat er kamfer van. daan kwam, daarbij uitgaande van het zeker geheel verkeerde beginsel om uit de producten tot de plaats te besluiten. I $\mathrm{k}$ zie er eene verbastering in van Maharadja, zoo als de vorst van Zabedj, d. i. Java, dikwịls genoemd wordt. Aan gelegenheid om namen te plaatsen ontbreekt het trouwens bij de Arabische aardrijkskundigen in deze streken niet. Men denke slechts aan humne voorstelling van eene in het zuiden gesloten Indische zee, zoodat de oostkusten van Afrika en die van den Archipel elkander raken, terwijl die vermeende zuidkust nu ook met namen bedekt is, en men zal kumnen begrijpen welk eene verwarring er hier heerscht. Zoo schijnt bijvoorbeeld de naam Komar, die in naauw verband met dien van Zabedj voorkomt, wel op het zuiden van VoorIndië, waar de kaap Koemari (tegenwoordig Komorin) ligt, heen te wijzen en is dat rijk dan ook werkelijk door Reinaud daar gezocht, maar even waarschijnlijk is het dat Madagaskar er mee bedoeld is.

Err blijven nu nog twee namen over, Senf en Senderfoelat, wier verklaring ook niet gemakkelijk is. Reinaud verwerpt, doch zonder iets anders te berde te brengen, het gevoelen van hen die Senf en Tjampa voor hetzelfde houden en zoekt Senderfoelat aan het begin der straat van Malakka. Boven zagen wij Senf voorgesteld als een rijk, waarop Senderfoelat volgt, dat of an het begin van de zee Saudji en of aan het begin òf aan het 
einde der Poorten van China gelegen is. Dat Sandji eene fout is voor Mandji en dat daarmeê de Chineesche zee bedoeld wordt is zeer wel mogelijk. Van Senderfoelat gaan de schepen dan regelrecht door naar Khanfoe.

Is het nu echter waarschijnlijk, dat van dit punt uit de schepen zoo direct naar Kanton of zelfs nog verder, wanneer Khanfoe het oude Gampoe is, zouden gevaren zijn? midden door zee, daar ze anders zoo angstig de kusten houden, en dat niet een afstand, als dien zij noodwendig over de golf van Bengalen moesten oversteken, maar twee driemaal zoo ver? en dat terwijl er onderweg nog zooveel gelegenheid was om hier en daar een eiland of eene kust aan te doen? vooreerst al dadelijk na het oversteken van de golf van Siam langs de geheele oostkust van Achter-Indië? Bedenken wij toch ook dat het Sin der Arabieren nog wel altijd het Sinai van Ptolemaeus is, en dus ook AchterIndië beteekent, zoodat die naam geen reden behoeft te zijn om Khanfoe in het tegenwoordige China te zoeken. Ook is Khanfoe nog geen Koean-tsjeoe-foe, en veel minder Sjang-Sjing, zoo als de Chineezen in het zuiden die stad noemen (eig. provinciehoofdstad). Ik zou daarom dien naam veel liever terugvinden in Kan-foe-tsje, d. i. Kambodja, de gelijknamige hoofdplaats van het bekende rijk, hetzelfde als het eenmaal zoo beroemde Angkor, aan de rivier Mekong, welks bouwvallen heden nog de verbazing der reizigers wekken en, laatstelijk door de commissie ter opneming van de rivier Mekong onderzocht en beschreven, nu ook weldra in Europa beter bekend zullen worden. Senf kan men nu ook voor het in de nabijheid gelegen Tjampa blijven houden, even als de Arabieren te Khanfoe van het rijk Anam kunnen gehoord hebben, welken naam men in dien van het eiland al-Ajam zou mogen zien. Ja zelfs zullen zij, die in Senderfoelat Poelau Kondor terugvinden, hierin een nieuw bewijs voor de juistheid van hun gevoelen zien, maar het blijft dan toch vreemd dat men Kondor-Poelau zou gezegd hebben, hetgeen, om die verbastering te verklaren, zou moeten worden aangenomen. Intusschen komen Marco-Polo's eilanden Sondoer en Kondoer het aangegeven vermoeden versterken. Doch er doet zich nog eene vraag op. Welke zijn die Poorten van China? Reinaud antwoordt, de eilanden tusschen Formosa en Tjoesan, dat zijn dus de Miakosima-eilanden. Doch die verklaring is natuurlijk gegrond op de veronderstelling dat Khanfoe zooveel noordelijker ligt, dan wij het plaatsen; neen, die poorten, die 
zee-straten, moeten bepaald op eene passage zien, die men door moet om in de Chineesche zee te komen, en niet op eene groep eilauden, die niemand behoefde te passeeren, die men rechts of links kon laten liggen of veeleer waar men niets mee te maken had, want de natuurlijke weg zou tusschen Formosa en het vaste land door geweest zijn. $\mathrm{W}_{i j}$ zullen hier de straten van Malakka en Singapoera hebben, zal men veeleer zeggen, en inderdaad de eilauden, daar men in deze langs moest, kouden niet onopgemerkt gebleven zijn, en zoo zou men dan ouder die poorten van China de poorten tot de Chineesche zee, dat zijn de eilandstraten van Oost-Sumatra en den Riouw-archipel moeten verstaan. Van daar uit zou, volgens Edrisi, de vaart nog maar kort geweest zijn om het einddoel der reis te bereiken, hetgeen zeker beter op Kambodja, dan op Kanton of Hangtsjeoefoe past. Zijn de poorten van China die straten niet - en zoowel die vermelding der bergen, als haar geringe lengte makt mij altijd nog wat huiverig dat voor zoo zeker te houden, - dan blijft mijns bedunkens maar een weg over en wel dwars door het vaste land. Ik zou namelijk willen weten of het Maleische schiereiland niet vroeger een eiland geweest is, dat door opheffing van den zeebodem op de hoogte waar zich thans de landengte Krah (is hier aan Kalah te denken ?) bevindt, later met het vaste land verbonden werd. Dat het land hier zeer laag is en slechts weinig zou behoeven te dalen om van de landengte eene zeestraat te maken, is bekend; daarbij neemt het Siameesche bergsysteem hier een einde om met eene andere richting in het zuidelijke overtegaan. Doch wij behoeven die verandering van zee in land niet eens aantenemen, als wij bedenken dat de binnenlandsche handel ook thans nog, om den omweg om het Maleische schiereiland heen te vermijden, dwars door die landengte heen gaat en wel langs drieërlei wegen, die alle in elkanders nabijheid liggen. Het lat zich zeer wel hooren dat ook in vroeger eeuwen deze de handelsweg geweest is, hetzij dan dat er een doorloopende waterweg was of niet, - trouwens die Poorten kumuen wel de rivieren geweest zijn, die ook tegenwoordig nog gebruikt worden om den landweg zooveel mogelijk te bekorten. Nemen wij aan dat dit in vroeger eeuwen evenzoo de gewone route geweest is, dan wordt het ons nog duidelijker hoe Katigara in Ptolemaeus' tijd het einde der reis was, want niet veel zuidelijker liggen die poorten van China, die een natuurlykeu slagboom vormden, dien men niet licht zal gepasseerd 3e Volgr. VII. 
zijn. Chineesche schepen zullen, gelijk nog heden ten dage het geval is, ook toen reeds dien handel verder hebben gedreven en zoo de Arabieren verder gingen, zal dit ook wel door Chineesche tusschenkomst geschied rijn. Ook eigennamen kunnen hun in Chineesche verbastering ter oore gekomen en daardoor voor ons nog onherkenbaarder geworden zijn. Zoo zou zelfs Selameth, in het Arabisch ook tot Selahith en Selahi verbasterd, wel eene Chineesche omzetting van het woord Sumatra (Soe-mate-la of liever misschien Sa-moe-te-la) kunnen zijn, waar de Arabieren zoo vroeg niet zullen heen gekomen zijn. Voor Sumatra wordt gewoonlijk gehouden ar-Ramni (ook Rami, Ramin, Ramana, Al-omri). Het meest afdoende bewijs daarvoor wordt hierin gezien, dat er daar kamfer-plantages, fansoer geheeten, zouden gevonden worden. $\mathrm{Nu}$ is Fansoer, dat door verkeerde uitspraak weder aanleiding gegeven heeft tot het scheppen van een eiland al-Kasr (قصر ,قنصور , فiصور), d. i. het kasteel, op welk woord al-Kazwini weder een geheel verhaal bouwt van een tooverkasteel, dat Alexander, door den glans er van verblind, te vergeefs trachtte intenemen enz, dat Fansoer nu is het tegenwoordige Baros, en dus Ramni Sumatra: aldus redeneerde men; en tot die verkeerde gevolgtrekking kan ook nog aanleiding gegeven hebben de naam Lambri van een voormalig rijkje op de noordkust van Sumatra, die met dat Ramni verward is. Dit toch is de naam van een eiland, dat ook thans nog eene bekende ververschingsplaats is voor de schepeu, die langs de kust van Arakán varen, en dat wij ook reeds vroeger hebben leeren kennen (Ptolemaeus en de Ind. Archipel bl. 54). Het is eene plaats, die nog al genoemd wordt in de Arabische verhalen; behalve bij Soliman komt rij ook nog voor bij Kazwini, Edrisi en Aboelfidá. In de route ligt het bij Soliman wel niet, maar wij hebben reeds gezien hoe weinig de berichten in die Relation des voyages eigenlijk van een goeden reisgids hebbeu. Hun gezag is volstrekt niet van dien aard, dat wij ar-Ramni buiten de rij der ververschingsplaatsen zouden behoeven te sluiten, die de schepen op hunne reis van Voor-Indië naar China aandeden. En om dat eiland daarin op te nemen, daarvoor pleit de omstandigheid, dat het èn heden nog, èn, zoo als wij waarschijnlijk gemaakt hebben, reeds in Ptolemaeus' tijd zulk eene landingsplaats was. Maar dan is nu ook de route, dien de Arabieren gevolgd zijp, geen andere geweest, dan die sedert eeuwen geyolgd en door de natuurlijke gesteldheid van winden en stroomen 
aangegeven was. Uit Voor-Indië stuurde men naar het noorden van de westkust van Achter-Indië, alwaar men het eiland Ramni aandeed, en ging van daar zuidwaarts, de kust langs, tot iets verder dan van waar Ptolemaeus nog berichten kreeg, om dan door de landengte Krah naar Kambodja over tẹ steken. Dat laatste gedeelte der reis kan misschien uitsluitend in Chineesche schepen gedaan zijn.

Veel meer dan namen leeren wij door de Arabieren niet kennen. Beschrijvingen, welke dien naam verdienen, geven zij van door hen bezochte plaatsen niet. Slechts noemen zij verscheidene handelswaren, die de kooplieden in die streken opdeden, waaronder er zijn die uitsluitend in den Archipel behooren, zoo als kamfer, kruidnagelen en notenmuskaat. Buitendien noemen zij vooral goud en ook misschien tin, ook kokosnoten en kokosolie, pisang, bamboe, rotting, sapanhout, wierook, paarlen, voorts olifanten, rhinocerossen en apen. Wat Edrisi verhaalt van eene tafel, die een reiziger zeide gezien te hebben, van één stuk hout gemaakt, waar 200 menschen omheen konden zitten eten, doet aan de tafels van Ambonsch wortelhout denken. Hị deelt echter die bijzonderheid van het eiland Komar (قمر) mee. Ook hebben blijkbaar de wilden, die met vergiftigde pijlen schieten en hunne natuurgenooten opeten, en ook de koppesnellers, waaronder natuurlijk niet uitsluitend de Dajaks behoeven verstaan te worden, diepen indruk op hen gemaakt. Kortom er zijn zoo eenige zaken, waaruit men zien kan, dat de Arabieren althans kennis gemaakt hadden met het verre Oosten, maar er zijn geen bewijzen voorhanden, dat zij de gewone handelsroute zouden verlaten hebben en zelf de meer zuidelijke eilanden hebben bezocht, immers niet voor in latere eeuwen. Ik sprak namelijk boven van een tweetal reizigers. Die andere, want Soliman kennen wij reeds, was Ibn-Batoeta. Deze bereisde een groot deel der toenmaals bekende wereld, meer dan iemand, voor zoover bekend is, voor of na hem ooit bereisd heeft, van 1325 tot 1353. Op zijue reizen kwam hij ook in Achter-Indië en begon daar zijne reis te Tjittagong in het noorden van A rakán, van waar hij reisde naar het eiland Djawah, dat is Sumatra, alwaar hij dicht bij de stad van dien naam (waarnaar ook het eiland genoemd werd) landde en er gastvrijheid genoot bij zekeren reeds tot den Islam bekeerden en ons ook uit inlandsche bronnen bekenden koning, Malik-et-Tahir. Daarna begaf hij zich aau boord van een Chineesch schip, waarmeê hij naar de landen 
der ongeloovigen voer. Misschien is Moeldjawah dat hij toen

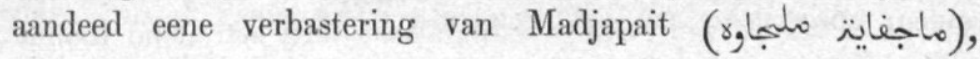
maar de namen die op de verdere reis voorkomen, Kakoela, Kailoeke en andere, zijn mij onbekend. Ook moet ik erkennen dat de vogel Rok, die ons uit de verhalen der 1001 Nacht zoo bekend is, hier, waar men op vaster bodem meent te staan, ons weer zonderling komt verrassen. Hij keerde over Sumatra naar Koelam, aan de kust van Malabar, terug. Zeker is het dat het gerucht van den vorst van Madjapait ook reeds vroeger tot de Arabieren was doorgedrongen. Zij noemden hem Maharadja en zijn rijk Zabedj (ook Ranedj enz.), een woord dat men aanstonds als verbastering herkent van Djabadioe. Wat zij van de uitgebreidheid zijner heerschappij verhalen, wordt bevestigd door hetgeen wij uit inlandsche bronnen weten, die ons ook meedeelen, dat het gebied van deu vorst van Madjapait zich over nagenoeg den geheelen Archipel uitstrekte. Maar bij geruchten, bij verhalen die meu elkaar meedeelde en wier waarde men wel niet te gering zal kunnen aanslaan, bleef het, en zelfs toen zich bij de zucht naar handelsspeculatien ook bekeeringsijver voegde, die de apostelen van den Islam tot vaste nederzetting in den Archipel bewoog, werd er door de Arabieren nog geen helderder licht over die landen ontstoken.

Vijf eeuwen liggen tusschen de reizen van Soliman en IbnBatoeta. In al dien tijd zijn de Arabieren de zeereis naar Indië en China blijven maken zonder ons directe berichten daarvan meetedeelen. Maar eene halve eeuw voor dezen laatsten reiziger hebben wij berichten van een Europeaan, die het verre Oosten van Azië bezocht en, wat meer zegt, ons eene uitvoerige beschrijving heeft nagelaten van de landen, die hij gezien heeft. Algemeen bekend is Marco Polo, de Venetiaansche reiziger, die zeventien jaren in dienst van den Grootvorst der Mongolen, Koebilai-Khan, heeft doorgebracht en wien het gegaan is als den vader der geschiedenis, Herodotus, dat zijne geloofwaardigheid meermalen betwijfeld is. Trouwens het was te vergeven, zoo men, om al het vreemde en fabelachtige wat hij opdischt, hem niet zoo spoedig vertrouwen schonk. Toch waren Quinsai, het tegenwoordige Hang-tsjeoe-foe, de prachtige hoofdstad van Zuid-China, toen de grootste stad der wereld, honderd mijlen (dertig uur gaans) in de rondte, doorsneden van kanalen, waarover twaalf duizend bruggen en de haven van Zeitoen, het tegenwoordige Tjioen-tjeoe-foe in Foekian, niet ver van 
Amoy, de groote markt voor peper, aloë, sandelhout en andere specerijen, en het goudrijke Zipangoe, Japan, vau welke Polo verhaald had, de plaatsen, die Columbus zich voorstelde te zullen bereiken, toen hij in 1492 den Atlantischen Oceaan overstak. Zoo uitlokkend waren die verhalen dan toch!

Japan heeft Marco Polo zelf niet bezocht, maar op zijne terugreis naar Europa, die hij van de haven Zeitoen uit over zee deed, heeft hij een deel van den Archipel gezien. Hij zeilde eerst naar Tjampa en van daar naar Groot-Java. Burck, Marco Polo's uitgever, meent dat hier met Groot-Java Borneo zal bedoeld zijn, en wel om de beschrijving, die er van gegeven wordt; maar wat de schrijver verhaalt van de goud- en specerijrijkdom van dat eiland is geen reden om het voor een ander eiland dan Java te houden. Integendeel, op het hoofdeiland van den Maharadja van Zabedj, zoo als de Arabieren het noemden, vloeiden al die waren van heinde en verre bijeen; de Chineezen dreven een leveudigen handel met Kiawa, zoo als Java bij hen heette, dat in Polo's tijd niet meer aan den Groot-Khan onderworpen was; Borneo was wel een goudland, maar een handelsstaat kennen wij er niet, waar dat goud zou zijn te krijgen geweest, en die specerijen moeten, Burck zelf erkent het, toch ook uit de Molukken daarheen gekomen zijn, die eilanden "die het ten oosten omgaven, van waar zij (de specerijen) gemakkelijk te krijgen waren " ! Was Burck maar wat beter op de hoogte geweest, dan had hij zoo niet geschreven. In zuid-oostelijke richting, zegt Polo, voer men van Tjampa naar Java-major heen. Dit gaat aan en brengt ons zelfs naar Oost-Java, juist waar wij zijn moeten. Doch nu komen de zwarigheden. Zuidzuidwestwaarts van Java, passeerende de eilanden Sondoer en Kondoer, ligt op het vaste land Lochak en meer zuidelijk of of zuidwestelijk van daar het eiland Pentan, en iets verder het koningrijk Malajoer. Zuidoostelijk van Pentan ligt Java-minor met zijn acht koningrijken, waarvan Polo er zes bezocht. Van daar komt men aan Nokueran en Angaman, blijkbaar de Nikobaren en de Andamanen, van welke hij dan verder gaat naar Ceilon. Er blijft dus ook geen twijfel over of Java-minor is Sumatra. Maar al wat er tusschen die beide Java's in ligt, is, zoo men onzen tekst woordelijk volgt, niet te verklaren. Toch schijnen de eigennamen vrij gemakkelijk terug te vinden. Zie hier hoe men ze verklaard heeft: Kondoer is Pau Kondoer (dicht bij de kust van Tjampa), Lochak, dat deel van Kambodja, waarvan de 
hoofdstad destijds Loech heette, Pentan is Bintan, Malajoer is Malakka. Men kan met die verklaring wel tevreden zijn, maar dan zou men toch ook nog willen weten of de handschriften en oude uitgaven toelaten den tekst, inzonderheid wat koersen en afstanden betreft, en juist hier zijn fouten zoo gemakkelijk te begaan, hier en daar anders te lezen. Is de verklaring goed, dan hebben wij hier het eerste duidelijke bericht van eene omzeiling van het Maleische schiereiland. In alle gevallen moeten wij, zoo de opgegeven route juist is, van de eene reis, zoo als Polo het thans voorstelt, er twee maken, en hem eerst van Tjampa naar Java en terug en dan van daar naar Sumatra laten reizen; of wij zouden het er voor moeten houden, dat de reis naar Java niet door Polo zelf is gedaan, tot staving van welk gevoelen men zich beroepen kan op wat Polo zegt, dat welonderrichte zeevaarders hem van Java verteld hebben, ofschoon ik zou gedacht hebben, dat die woorden alleen op de grootte van het eiland slaan.

Van de zes rijken van Sumatra, die Marco Polo zegt zelf bezocht te hebben, kumnen wij in drie met voldoende zekerheid Perlak, Lambri (lag vroeger in de buurt van Atjih) en Fansoer terug vinden; de verklaring der drie andere door Pasei, Samoedra en Indragiri komt mij jets minder zeker voor. Op Perlak na waren al die staatjes aan den Groot-khan onderworpen, en daar alleen vond Polo ook Arabieren, die er veel kwamen en de inwoners reeds gedeeltelijk tot den Islam bekeerd hadden. De overige staatjes waren nog door heidenen bewoond.

Wij zien hier dus bij Polo de eerste morgenschemering van den nieuwen dag; enkele namen, wier geschiedenis wij sedert bij de eenen wat beter, bij de anderen wat minder, vervolgen kunnen. $\mathrm{Na}$ hem komt nu nog eens een Ibn-Batoeta, bij wien wij nog een schijn terugvinden van de fabelen van vroeger dagen, maar. die van de noordkust van Sumatra al wat meer weet te vertellen, en daarmee sluiten zich de middeleeuwen, om, ofschoon altoos nog een paar eeuwen later, plaats te maken voor den nieuwen tijd, die met de komst der Portugezen in den Archipel begint. -

Er is iets dat met het hier behandelde in naauw verband staat. Het is de komst en vestiging der Arabieren in den Archipel, de vraag van waar en langs welken weg zij daar kwamen? Wanneer zich echter aan die vraag niet nog een paar 
quaesties van meer belang hechtten, dan zoude zij ons vrịj onverschillig laten. Met die komst van de Arabieren staat namelijk hun godsdienst weer in naauw verband en naast den Arabischen invloed schijnt er ook een Perzische te bestaan. Hierover nu nog een enkel woord.

De oudste Arabische zeehandel ging uit van de Perzische golf en van daar, de zuidkusten van Perzië en de westkusten van Voor-Indië langs, zuidwaarts. Van den anderen kant kwamen de Chineezen en de Indiërs zelf dienzelfden weg langs noordwaarts, doch met het uitbreiden van den handel der Arabieren en Perziërs schijnt die der Indiërs en Chineezen ingekrompen, die der eersten zelfs zoo goed als geheel opgehouden te zijn. Er waren reeds in oude tijden een paar belangrijke handelsteden op de westkust van Voor-Indië. Het tegenwoordige Barotj, toen Barygaza, en bij de Arabieren Beroeh, in Goedjerate, werd later door Soerate als handelstad overschaduwd; Quilon, vroeger Koelam, in Zuid-Malabar, is nog altijd een plaatsje van naam, al is deze niet meer zoo beroemd als vroeger. In het begin der $9_{\mathrm{e}}$ eeuw deden de Arabieren reeds bedevaarten, vaarten liever, waarop handel met verkondiging van den Islam gepaard ging, naar Ceilon, waar de heilige Adamspiek hen aantrok, en op een van die reizen, uit Goedjerate oudernomeu, zouden zij door een storm beloopen en op de kust van Malabar geland, aldaar den Zamorin, dat is den vorst des lands, tot den Islam bekeerd hebben. Van toen af waren de Arabieren aan die kust in groot aanzieu.

In bijzonderheden weten wij van dit alles nagenoeg niets meer en ik weet niet of er over dit punt ooit zeer veel nieuw licht zal opgaan, hoezeer het, ten einde den oorsproug der Arabische godsdienst en heerschappij in den Indischen Archipel in een helderder licht te plaatsen, wel de moeite waard zou zijn dit nog eens opzettelijk te onderzoeken. Doch hetgeen wij, nu reeds weten, doet ons de oorzaak vermoeden, waarom wịi vooral in de oudere geschiedenis van den Arehipel, dien naam van Malabar en Goedjerate zoo menigmaal aantreffen, en ook die Perzische invloed laat er zich gedeeltelịk, ik zou niet willen beweren geheel, uit verklaren. Eindelijk kunnen wij er de reden uit opmaken, waarom de godsdienstige secte der Arabieren in den Archipel niet die der Hanafiten, die men in Engelsch-Indië het meeste aantreft, maar die der Sjafiiten is, die in Egypte en Arabië t'huis is. De Arabieren van Malabar namelijk be- 
158 OVER DE KENNIS, DIE DE ARABIEREN VOOR DE KOMST ENZ. hoorden tot de laatstgenoemde secte en het schịnt vrij wat eenvoudiger aan hen de verbreiding van den Islam in den Archipel toeteschrijven, dan het Sjafiitisme uit Kaïro te doen komen, zoo als de schrijver van het "Précis de jurisprudence musulmane selon le rite Châfeite" gedaan heeft.

Leiden, Augustus 1872. Dr. J. PiJnappel. 